\title{
The Visegrad Cooperation in the Context of Other Central European Cooperation Formats
}

\author{
LADISLAV CABADA
}

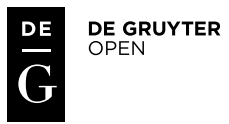

Politics in Central Europe (ISSN: 1801-3422)

Vol. 14 , No. 2

DOI: $10.2478 /$ pce-2018-0014

\begin{abstract}
This study considers the plethora of contemporary institutional frameworks for Central European cooperation. While the Visegrad Group has been the most visible and stable format for Central European cooperation in recent history, it has been challenged by a number of alternative or complementary projects. These include the Austrian concept of Strategic/Regional Partnership, the Austrian-Czech-Slovak project Austerlitz-Formate/Nord-Trilaterale, the Polish-Croatian Three Seas Initiative and the European Union's macro-regional Strategy for the Danube Region (EUSDR). I focus on the development and prospects of each of these projects as well the rivalries among them and their intersections ot interference with one another. This survey then turns to the future Central European constellations suggested by the very different cooperation trajectories within the region. My thesis is that the region's identity has been challenged by offers to merge with Europe's West. Central European cooperation must find new challenges and themes if it is to survive.
\end{abstract}

Keywords: Central European cooperation formats, Visegrad Group, Austerlitz-Formate, Three Seas Initiative, Strategy for the Danube Region, spaghetti bowl effect

Central European regionalism builds on a tradition that is at least two hundred years old. The origins of this tradition are usually linked to the Vienna Congress and the demarcation of Central Europe as a "space in-between" that was surrounded by two Western actors (France and the United Kingdom) and three Eastern (Prussia, Austria and Russia) actors under the Concert of Europe. As a result of Germany's growing power and influence, the epicentre of Central 
Europe moved from the Netherlands-Switzerland-Italy axis to the East and, by the mid-19th century, the region had stabilised based on its links to the Habsburg Empire and its effort to preserve a distinct Central European identity alongside Germany. In contrast, Germany, which was unifying under Prussian leadership, promoted the equivalence of Central Europe with the German state. During the inter-war period, Central Europe became a region of small nation states gripped by a critical security conflict: this was the cleavage between the German and Russian/Soviet states with their aggressive geopolitical visions of regional absorption and/or division. This situation ultimately led to the incorporation of a large part of the region into the Soviet bloc/Eastern Europe. It has also caused Central European intellectuals to reflect on the specific cultural identity of Central European nations compared with that of East European nations (cf. Cabada - Walsch 2017).

While debates and considerations about the region's shared geopolitical fate and its hundred-year-long effort to "catch up" with the West dominate Central European regionalism today, critics often overlook key features seen in other traditional European transnational regions (for example, in the Benelux and Nordic groupings). However, the most distinctive element of Central European regionalism neglected in these discussions is the sense of identity that has developed over time at all societal and institutional levels, and above all, the civic identity that has been cultivated from the ground up. This civic identity could be observed to some degree at least in the dissent movements of the 1970s and 1980 s, but it also had its roots in smaller traditional intellectual epistemic communities. From the very outset, the Visegrad cooperation was a product of these movement(s) that - based on historical coincidence - took hold in three and eventually four Central European countries during the democratic transition. However, as early as 1993, the same traditional forces that have intruded on integration elsewhere were evident in the V4 and Central Europe - these included mutual rivalries, the prioritising of national over regional interests, competing visions of regional cooperation including its membership and configuration and efforts to dominate. While the V4 have succeeded several times at revitalising their mission in order to enforce common interests, the group can hardly be called the only or definitive platform for Central European cooperation. This means that the V4 states see - and occasionally have also searched for - alternatives.

Certainly the V4 group remains the most significant format for Central and East-Central European regional cooperation today. Nevertheless, this cooperation has been compromised repeatedly and - in some analysts' view - irreversibly by the lack of any internal regional identity or common regional interest that would override the national interest(s) of individual states. One reason for these complications is Poland's predominance within the V4 based on the country's size and multi-vectoral policies. A second cause may be the internal 
conflicts over some (European) policies. Last but by no means least, we must note the actions of certain external actors who do not accept their "peripheral" status in (East-)Central Europe when faced with the "core" position of the V4 in the region. Here we should mention not only Austria but also Croatia and Slovenia. These are, in any case, some of the factors that may be behind the initiation of new and/or parallel regional integration activities.

Set against this backdrop, this article aims to reflect on contemporary discussions about the Visegrad Group and other/alternative (East-)Central European cooperation formats and their respective definitions of the Central European region. My main hypothesis is that individual states within the often addressed Central and East-Central European area are striving to reconfigure Central European cooperation formats to promote their own national interests. These states use either their non-formal alliances with the Visegrad Group or new/existing cooperation formats to advance their activities and goals. This hypothesis also holds true for the $\mathrm{V} 4$ members themselves. In this regard, we may point to (occasional) moves to discharge the cooperation and/or replace it with other formats. These moves reflect internal politics, ideological preferences, attempts to gain distance from the leaders of certain member states and relations with "external" actors, most critically the EU.

\section{The V4: A relatively stable but "toxic" community}

Despite repeated crises and a loss of internal cohesion resulting from a range of factors, ${ }^{1}$ the Visegrad Group remains the most prominent and successful Central European cooperation format. This formal cooperation, created following the lack of interest of Austrian diplomats in the early '90s in fostering Central European cooperation based on "Habsburg-era nostalgia," has persisted for more than 27 years. Nevertheless, it would be difficult to argue that the Visegrad Group is a permanent constellation.

In my view, the main advantage of the Visegrad arrangement is the absence of any institutional demand for "permanent" consensus among the member states. As such, the V4 may be reduced for long periods to formal meetings of prime ministers and government members where no fundamental issues are presented. In contrast, there are issues - EU budget negotiations, resistance to the EU's highly environmentally-focused energy policy, opposition to illegal migration and relocation quotas, etc. - around which the group can cooperate very intensively. Furthermore, based on this V4 format, the group is able to attract other partners for ad hoc cooperation. This usually refers to other newer EU members from the group of former Communist states, but in particular

1 Some of the causes of these crises/ruptures include the Klaus governments in the Czech Republic, Slovakia's Mečiarism period, opposition to certain post-2010 policies of Hungarian Prime Minister Orbán and Poland's increased focus on hard security. 
instances, can extend to other partners (for example, the European southern nations, Austria and the United Kingdom).

This means that we can understand the $\mathrm{V} 4$ as a stable regional group although its regionness" is greatly limited both in form (given the dominance of intergovernmental cooperation and the almost complete lack of any bottom-up regional identity) and content (given the absence of positions shared by all four countries on many important policies and issues). This situation has given rise to both critique and the realist position that despite all the problems, the V4 is the most successful regional activity in Central Europe. The criticisms have been well summarised: "The V4 countries were not able to elaborate jointly the infrastructural projects, to talk with one voice in the EU and NATO, collectively define the risk areas and cooperate in the process of their elimination. The V4 economies do not produce positive synergies, but strongly compete among themselves - mainly with effort to attract the foreign investments. The $\mathrm{V} 4$ also does not produce a "mark": it is still weakly organized, also within the societies of the member states. The V4 does not create the network for the cooperation, as we can observe in the cases of Benelux or Nordic cooperation“" (Kużelewska - Bartnicki - Skarzyński 2015: 146).

These scholars also point out that each of the member states understood the V4's creation differently: "For Poland it was the instrument of balancing between Russia and Germany. For Slovakia - the opportunity to step out from the political isolation and become [a] fully-fledged member of the region. Poland, Czech Republic and Hungary declare the aspiration to lead the group. Poland as the biggest nation with the biggest economic growth seems to be [the] natural leader. Nevertheless, [this] idea is not shared by the other members" (Kużelewska - Bartnicki - Skarzyński 2015: 158).

In response, Kořan (2012: 201) has called the V4 a "subregional group," meaning that Central Europe is more extensive. He stresses the group's "surprising ability to overcome long and repeated phases of justified scepticism," noting that " $\mathrm{t}]$ he $\mathrm{V} 4$ serves as the hub $[\ldots]$ as the messenger and promoter of Central European visions in [a] broader European context." Like some other authors, he is convinced that the socialisation associated with democratic consolidation, Europeanisation and regional integration "led towards something that might be marked as Visegrad quasi-identity." This quasi-identity has had no distinct impact on the societies of the Visegrad countries, but it is "deeply rooted in the thinking of politicians, diplomats and other official representatives that engage in international policy." The quasi-identity is also tied to a sense of quasi-institutionalisation. This is shown by the fact that politicians, officials, foreign policy commentators and scholars regard the V4 cooperation as natural and tend to prefer it to other formats like the Central European Initiative or the Regional Partnership. At the same time, we may question the extent to which Kořan's position remains valid six years after he made these observations. This is especially important in the cases of the Austerlitz alliance 
and the Polish-Croatian Three Seas Initiative, i.e. the alternative cooperation formats that I analyse below.

According to Kořan (2012), the Visegrad Group exchanged its rather defensive style for a more pro-active approach after 2009, having announced its ambition to become an essential driving force behind European integration. The V4 group, he notes, has united around three clearly stated goals and policies: support for the eastern and south-eastern vectors of EU enlargement; support for the eastern dimension of the European Neighbourhood Policy and a shared vision of regional energy policy. My own analysis confirms this view of the V4's focus and priorities. Nevertheless, it is worth observing that these themes have clearly overlapped with the group's resistance to mainstream EU migration policies since 2015. The desire to become an alternative "core" or engine of the European Union has been overshadowed by the group's problematic image. As the Hungarian political scientist Boglárka Koller stressed during the debates on Central European cooperation at a recent Central European Political Science Association (CEPSA) conference, ${ }^{2}$ while Western Europe sees the V4 states as stragglers, these nations understand themselves as pioneers.

Wientzek (2017: 47) emphasises that regional cooperation may be both a driver and an obstacle to European integration: "It may, however, also function as a brake or serious obstacle to the European integration process if it becomes a cartel, acting against the EU's interests and thus causing serious damage to the European integration project as a whole. The Franco-German disregard of the Stability and Growth Pact in 2003 is one negative example".

As a result, Wientzek appeals to the V4 to promote a "positive agenda." In his view, the V4 has come to be defined by its position on the migration crisis, a situation that has typecast it as a "negative coalition." While this characterisation is simplifying and distorted, it does capture the important fact that the V4 group is seen as a "purely defensive project" at European level.

Similarly, Hokovský (2017: 53) argues that because of the sharply different positions and economic rivalries that have emerged over Visegrad Group's history, it has "not played a visible or influential role within the European Union. This has changed with the migration crisis of 2015." This argument emphasises that the demand of V4 leaders to stop illegal migration in 2015 - a position formulated in opposition to the EU mainstream - had become the general message of most EU member state politicians by 2017. Nevertheless, the reality that the leaders of most EU states adopted the positions of V4 country leaders has not erased the group's negative and even "toxic" image. As Hokovský (2017:54) puts it: "Strong statements of criticism and refusal, unaccompanied by constructive proposals, have not helped Western politicians to understand and appreciate the Visegrad positions. Apart from the restrictive approach to migration, the

2 This was the 23rd annual CEPSA conference held in Wroclaw on 14-15 September 2017. 
V4 has become known for the controversial constitutional moves by the governments in Budapest and Warsaw. These illiberal tendencies have only reinforced the image of Visegrad as a regressive group of post-communist societies unable to fully integrate with post-modern multicultural open-minded Europe".

According to this account, the clear dominance of the France-Germany duo and more generally the "western" part of the EU has confined the V4 to the role of an obstacle. Such an obstacle may, however, be seen as destructive/subversive or as a source of "healthy and constructive regulation."

In sum, it is clear that both sceptics and optimists believe the V4 group is a stable regional cooperative structure that will continue to exist - at least formally - in the future. This group has the potential to be a fairly assertive proponent of broader (East-)Central European or even Europe-wide alternatives to the EU engine represented by France and its main partners (the Benelux Group). At the same time, the V4's current negative image could lead (some) EU member states to seek out alternative cooperation formats within the Central European region and/or avoid the "toxicity" of Visegrad membership.

\section{Alternative formats of Central European cooperation}

As we have seen, at the beginning of the 1990s, the Visegrad constellation was particularly influenced by Austria's lack of interest in developing a partnership with the democratising post-Communist states of Central Europe. Austria clearly preferred the option of early membership of the European Community, which had taken shape at the end of Europe's bipolar division. With this goal fulfilled, Austrian diplomats began to contemplate a more active role in the Central-Eastern region. One concrete outcome of this shift was the Regional Partnership proposed by Chancellor Wolfgang Schüssel's new government in 2000. Austria invited its Czech, Hungarian, Slovak and Slovenian neighbours to join and extended the invitation to its "cultural neighbour" Poland. The initiative's original title, "Strategic Partnership," was rejected by the invited partners and replaced with a more neutral-sounding name that stressed the alliance's "regional" character. In these early years, the Regional Partnership had the basic objectives of supporting partner nations in their preparations for EU membership and defining and promoting their shared interests in the Union.

Three key Austrian concerns had a decisive effect on the development of the initiative. The first of these was the Austrian economy, which like the economies of other EU-15 nations, stood to gain from the EU's eastern enlargement. Austria, thus, promoted the shift from bilateral to multilateral/regional relations with the (East-)Central European states. The second factor was the sanctions imposed on the new Austrian government in the first half of 2000 after the election of the populist Freedom Party (Freiheitliche Partei Österreichs, FPÖ) led by Jörg Haider. Feeling abandoned by other EU member states, Austria was keen to 
find new strategic partners. The third driver, though never officially stated, was the country's wish to play a more important role in Central Europe. It must be stressed that Austria was not included in the Visegrad cooperation. Moreover, as a non-NATO nation, it was not privy to certain communications channels about security policy. Nevertheless, the Austrian government maintained that a strategic or regional partnership was justified on the basis of many other common issues (Kiss - Königova - Luif 2003).

The Regional Partnership attracted considerable scepticism from among the invited nations. It was dubbed the "V4 plus Austria and Slovenia" and greeted especially coldly by countries with complicated bilateral relations with Austria, particularly the Czech Republic and Slovakia, which had security concerns about their nuclear power plants. Polish diplomats were also fairly critical and from the very start viewed the Austrian activity from the standpoint of representatives of a "real" regional power. On the other hand, this initiative was clearly intended to compete with the existing V4 format, and since Slovenia had stayed out of that arrangement, it welcomed the developments (Cabada - Walsch 2017: 118).

There were also less cynical voices within the Czech Republic, who asked whether a modified Regional Partnership might be a good alternative to the Visegrad cooperation. The most discussed issue was the possibility of excluding Poland from the Central European cooperation as a large nation whose interests differed to some degree from those of the smaller Central European states. As examples of these differences, critics noted Poland's "high-power" cooperation with France and Germany in the Weimar Triangle (Smith 2007: 279-280), its role in the EU's Eastern policy and its predominance within the V4 group. Sceptics responded that the Regional Partnership would be a community of small(er) Central European nations. Naturally, some also objected that this constellation even more than a Regional Partnership including Poland - would appear like a "revival" of Habsburg-era Central Europe (Walsch 2015: 94-97).

Another reason for the Austrian proposal's cold reception was the failure to establish supportive institutional structures. Instead meetings were limited to the discussion of fairly extensive cooperation based on current impulses and needs. By far the most successful area of cooperation was justice and internal affairs, which was handled through the Salzburg Forum for cooperation among interior ministers and officials from their departments. The forum's overriding concerns were internal security related to the Schengen Area enlargement, combating terrorism and cooperation related to third countries, for example, through the use of shared consulates and the coordination of visa matters. Like the "V4+" format, this forum proved flexible when it came to member numbers, and as such, the Western Balkan states were often included in internal security matters (Walsch 2015: 236-238).

This cooperation around internal affairs revealed the interest of the new member states in working with Austria, especially in areas where the collabo- 
ration had been shown to have added value. In the case of the Salzburg Forum, the integration of these states into the Schengen Area in December 2007 and subsequent coordination activities were seen as proof of this value. In other political spheres, however, there were not such obvious signs. This is also why official promotions of the Regional Partnership stopped in 2012. Around this time, Austria announced its plans to promote its interests through existing regional and European institutions. However, this decision was set aside less than three years later when Austria joined with the Czech Republic and Slovakia to establish the Austerlitz group. Since 2016, Austria has also been one of the members of the Three Seas Initiative, a broad regional alliance set up in cooperation with Poland and Croatia.

The Austerlitz Triangle or Nord-Trilaterale is an intergovernmental cooperative arrangement among Austria, the Czech Republic and Slovakia that was officially launched in January 2015. Czech diplomats cited the convergence of Austrian and V4 interests as one of the goals of this group. However it is more than clear that the intention of the three governments, dominated by their respective Social Democrat prime ministers Werner Feymann, Bohuslav Sobotka and Robert Fico, was to distance themselves from conservative nationalist governments in Hungary and Poland. Given the subsequent victories of Sebastian Kurz in Austria and Andrej Babiš in the Czech Republic and their still unclear positions on the EU and regional integration, it is hard to say whether the Austerlitz Triangle will replace the V4 or lead to an "improved V4" arrangement that could eventually include other countries (Slovenia, Croatia and perhaps even Hungary, which would displace Poland from this narrower Central European configuration). It seems more likely that discussions will resume about the potential expansion of the V4, either through the incorporation of Austria alone or by some larger enlargement (including Croatia, Slovenia and Romania). Any such enlargement would, however, bring the V4 closer to the format of the Three Seas Initiative, which would make these steps senseless (Cabada - Walsch 2017: 210-211).

The Three Seas Initiative is a new and highly ambitious attempt to promote broad regional cooperation in East-Central Europe, i.e. in the area between Germany and Russia. Polish diplomats have been observing other V4 states' efforts to make alternative regional arrangements with a mix of concern and contempt. Aside from the Austerlitz Triangle, these projects include Hungarian cooperation with Croatia and Slovenia in the "HCS Triangle" and the EU's macro-regional Strategy for the Danube Region (EUSDR), which since April 2011, has linked nine EU member states, three candidate states and parts of two Eastern Partnership states from Baden-Württemberg to the Danube delta; it has, however, left out Poland (cf. Bos - Griessler - Walsch 2017). After Poland's parliamentary elections and change of government at the end of 2015, it proceeded to develop its own project. The Three Seas Initiative is, then, the 
effort of the most dominant nation in (East-)Central Europe to take charge and establish a regional cooperation platform far broader than the V4.

Poland and Croatia officially launched the project in 2016. Representatives of 12 countries were invited to its first summit in Dubrovnik, Croatia in August 2016. Aside from Austria, all of the invited parties were post-Communist EU member states. Poland, at the helm of the new initiative, presented the move to strengthen the North-South European connection as a corrective to the current emphasis on the West-East axis. The main focus of the cooperation was said to be economic, partly with a view to security. Attended by a representative of the Chinese New Silk Road initiative (no official representatives of the EU or the European Commission were invited), the Dubrovnik summit paid particular attention to energy, transport and communication infrastructure, highlighting the Klaipeda-Thessaloniki highway and gas pipelines supplying East-Central Europe from Polish and Croatian liquid gas terminals (LGT). At a second summit held in Warsaw in July 2017 in parallel with US President Donald Trump's visit to Poland, the Three Seas Business Forum was established (Wiśniewski 2017).

While Polish diplomats strongly reject the view that the Three Seas Initiative continues the country's interwar Intermarium project, which had a significant "imperial" component, it cannot be overlooked that - as in the case of the V4 Poland is the lead and dominant actor in the group. Furthermore, it should be recalled that the Initiative was launched less than two years after the creation of the Austerlitz Triangle and may, thus, be seen as an effort to ocercome the emerging V4-Nord-Trilaterale rivalry via a brand new cooperative platform. The main challenge and risk for the Initiative lies in the fact that with the sole exception of Austria, its creators were all post-Communist nations and it mechanically takes up the EU division between West and East. This split may have been useful when creating a coalition at European level but it has unwittingly set the stage for a multispeed Europe. As such, many East-Central European nations (for instance, Slovakia, Slovenia and the Baltic states) have opposed this proposal, and it is unclear how stable their ties with the Three Seas Initiative are and will continue to be.

Despite these rather lively developments around (East-)Central European cooperation formats in recent years, the Visegrad Group has remained the favoured framework for joint action. In my view, there is currently no alternative or overlapping alliance that could replace or challenge the V4. Turning to macro-regional formats, the EUSDR's structural-functionalist project could significantly affect the agenda of its member states and the overall region (in the case of the V4 members, this would have the greatest impact on Hungary). Nevertheless, these activities are not - and are unlikely to be seen as - an alternative to the V4. The same may not be true of the Three Seas Initiative, which could lead to the permanent institutionalisation of the "V4+" format in its most expansive form (including all post-Communist EU member states and Austria). 
On the other hand, important differences have already emerged among the four V4 nations when it comes to their "ideal" solutions to important issues and policies. Within a group of 12 countries, the search for common interests and regional solutions would be far more complicated. It is, for example, very hard to imagine a comprehensive set of themes that could be shared by Austria and Bulgaria. Some Initiative member states support the idea of a common European currency or even the strengthening of the EU's core. In contrast, other members have ongoing conflicts with the rule of law and delight in the prospect of permanently opposing "Brussels."

\section{The V4 as a stable structure with unclear prospects}

Does the fact that the V4 group has stayed relatively stable in the face of other (East-)Central European cooperation formats mean it is protected from decline or even disintegration?

At the outset, we need to distinguish between the V4's formal existence (as shown by financial transfers to the group's only institutional body, the International Visegrad Fund, and occasional meetings of member state politicians) and the true working cooperation that is based on shared interests, priorities and - above all - implementation strategies. The history of the $\mathrm{V} 4$ has seen the group break up at different times into two "mini-groups" either in the form of a " $3+1$ " or a " $2+2$." 3 This was the case, for example, immediately after the division of Czechoslovakia when the Klaus government distanced itself from the cooperation. Later Slovak Prime Minister Vladimír Mečiar also assumed a pose of "internal opposition" as his country veered towards illiberal democracy. Hungary has repeatedly been isolated in the group, largely due to its critique of the Beneš decrees (Poland has exercised self-restraint on this issue). The period 2015-2017 saw more internal rifts with the Czech Republic and Slovakia using the Austerlitz Triangle to dissociate themselves from conservative nationalist and deeply Eurosceptical governments in Hungary and Poland. These splits were exacerbated by the actions of external players such as newly elected French President Emmanuel Macron. Soon after his election, Macron described the V4 group's approach to the migration crisis and especially its rejection of relocation quotas as "tricky and cynical." During a trip to Eastern Europe in August 2017, he used the Austerlitz Triangle to call out the two "problematic" actors - Hungary and Poland - as well as the more promising pair of the Czech Republic and Slovakia. Macron's meeting with the Czech, Slovak and Austrian prime ministers in Salzburg on 23 August 2017, and a subsequent trip to Bulgaria, bypassing Budapest and above all Warsaw, reaffirmed the French recognition of a 2+2 format within the V4 group (Cabada - Walsch 2017: 206).

3 Confirming these divisions, Dostál and Végh (2017) stress the clear societal affiliations between Czechs and Slovaks on the one hand and Poles and Hungarians on the other. 
At the same time, given the post-election situation in the Czech Republic in the autumn of 2017, and especially the assertions of the main Czech foreign policy creator Prime Minister Babiš, the $2+2$ seems likely to revert to a $3+1$ model. Indeed, we may assume that the new Czech government will steer towards the positions of Hungary and Poland and away from those of Slovakia. In contrast, since the October 2017 Czech elections, Slovak leaders have clearly conveyed their nation's preference for the positions of the EU core over any other alliance, including Central European regional formations. Putting all this aside, I do not believe that the disintegration of the V4 group is on the cards. Rather, in the coming negotiations over the 2020-2027 EU budget, there is real potential for V4 members to create and lead a "Friends of Cohesion" group. This may be one of the last actions taken by this rather negative coalition that seeks to limit and prevent changes to the logic of funding distributions. Slovakia at least (and perhaps also the Czech Republic) has expressed a desire to propose relevant topics rather than "only" reacting negatively to the agenda of other actors, especially the France-Germany dyad.

If we reject the simplistic position that all post-Commu- nist states are essentially alike, it is clear that Central Europe differs from the "rest" of East-Central Europe mainly because of its better economic and general development conditions. On this understanding, Central Europe is the "semi-periphery" between the centre/core of the West and the periphery of the (South-)East. It follows that incorporation into a bigger group of East-Central European countries - particularly through the Three Seas Initiative approach that splits the EU into West and East - would delay the Central European countries' move towards and inclusion in the (economic) core. It may appear that nothing has changed concerning the dilemma that Central Europe faced before EU accession, i.e. the prospect that EU membership would likely lead to a weakening of regional identity. Back in 2002, Waisová stressed: "The Central European region can today be understood as a transitory region that may be incorporated into the core region represented here by the EU. The rate and speed of that incorporation will depend on the Central European region's actions, which must comply with the expectations and behaviour of the core itself (acceptance of the EU's laws and values, adoption of EU institutions). The Central European region's incorporation into the EU's core will most likely lead to the weakening of Central European regional identity and subsequently to the gradual downgrading and disintegration of Central European regional structures" (Waisová 2002: 66).

Given the V4's apparent revitalisation around the migration crisis and the growing number of Central European integration projects, it may seem that this assumption has not borne out. Certainly, one reason for this may be that some Central European governments have substantially reduced their efforts to integrate into the core region (Western Europe) or become part of a stronger and deeper EU framework. In other words, these Central European nations are 
supporting slower options/arrangements based on the notion of a multi-speed EU or flirting with the idea of "another Europe." Arguably, the debate about these issues is fundamentally at odds with the mission of Central European integration projects including the V4. The belief that developments and political priorities inside Hungary and Poland contravened Central Europe's vital interest in overcoming its (semi-)peripheral position and joining the EU core, was one of the most important drivers of Czech, Slovak and Austrian cooperation in the Austerlitz Triangle. This cooperation aims to promote a "more positive" Central Europe outside of the V4. Czech diplomats have also revived a Czech-German strategic partnership project, which should offer an alternative to Central European cooperation.

It is, however, Slovakia that has been clearest about its preference for pro-European arrangements over regional ones. Even before learning the results of the 2017 Czech elections, Slovak Prime Minister Robert Fico made clear that his country would not risk exclusion from the emerging and/or potential EU core for the sake of the Visegrad or any broader Central European cooperation. He also warned that the Visegrad alliance could be a casualty of Slovakia's position within the EU core: "For Slovakia, the Visegrad Four is not an alternative to the EU. For Slovakia, the V4 is not the place we imagine living in the future. Our place is in the EU” (Fico pospíchá do jádra EU 2017).

The success in the Czech elections of protest parties with a reserved or openly negative stance on the EU dashed any hopes of the re-liberalisation and re-Europeanisation of the $\mathrm{V} 4$ via the Austerlitz Triangle. In response, the Slovak prime minister's position was even more pragmatic and resolute. Two days after the elections, he met with Slovak President Andrej Kiska and national parliament speaker Andrej Danko and released a joint communiqué confirming Slovakia's pro-European and pro-Western allegiance based on a commitment to EU and NATO positions. Later, Prime Minister Fico presented this statement to the media, describing Slovakia variously as an "island" and a "pro-European island in Central Europe" (Slovensko je proeurópsky ostrov 2017). This was a loaded critique aimed directly at the V4 partners since the "island" metaphor has particular historical resonances in this region. Czechoslovakia's interwar foreign minister and later president often used this metaphor to stress the democratic nature of his state compared with Hungary and Poland. Despite these developments, Fico's actions during a February and March 2018 domestic crisis - including his allegations of foreign interference and a direct attack on George Soros - suggest the country's position (pro-European pragmatism) may be as schizophrenic as the one of its Hungarian neighbour.

At the close of the first quarter of 2018, the Visegrad Group appears to be slightly unsettled and lacking in not just a strong regional identity but also a clear goal and raison d'être. As the group's hegemonic power, Poland continues its efforts to create a broader framework for its regional command. This is, it 
believes, the best way to counteract Europe's "West." Like Hungary, the country opposes the current course of European integration. Instead, it has relativised the rule of law and developed a conservative nationalist democratura that threatens to make it the pariah of the EU. In contrast, Slovakia and, after some doubts and deflections, the Czech Republic are exploring a more conciliatory approach to the EU's core though they too are ready to use the V4 to criticise EU policies, particularly on migration. In recent years, all of the $\mathrm{V} 4$ member states have explored the creation of parallel alliances and regional projects that could give them a platform if they decide to leave the V4 or - more likely - to take an "empty chair" approach within the group.

\section{References}

Bos, E. - Griessler, C. - Walsch, C., eds. (2017): Die EU-Strategie für den Donauraum auf dem Prüfstand. Erfahrungen und Perspektiven. Baden-Baden, Nomos Verlag.

Cabada, L - Walsch, C. (2017): Od dunajské federace k Visegrádské skupině... a zpět? Tradiční a nové formáty středoevropské spoluprácem. Prague: Libri and MUP Press.

Dostál, V. - Végh, Z. (2017): Trends of Visegrad European Policy. Prague: AMO.

Drulák, P. - Šabič, Z. (2012): Conclusions: Institutions, Geography and Uncertainty, in Šabič, Z. Drulák, P., eds., Regional and International Relations of Central Europe, 310-316, Houndmills, Palgrave Macmillan.

Hokovský, R. (2017): The Role of Visegrad Group in the EU: The View fro the Inside. In Tungul, L., ed., The Czech Centre-Right Solutions to the Political Challenges of 2018, 51-55, Prague, Wilfried Mertens Centre for European Studies, Konrad-Adenauer-Stiftung a TOPAZ.

Fico pospíchá do jádra Evropské unie (2017), Dnes (14 September): available at https://www. novinky.cz/zahranicni/evropa/449147-fico-pospicha-do-jadra-evropske-unie.html (14 September 2017)

Kiss, L. - Königova, L. - Luif, P. (2003): Die "Regionale Partnerschaft". Subregionale Zusammenarbeit in der Mitte Europas. Österreichische Zeitschrift für Politik 32 (1): 57-75.

Kořan, Michal (2012): The Visegrad Group on the Threshold of Its Third Decade: A Central European Hub?, in Drulák, P. - Šabič, Z., eds., Regional and International Relations of Central Europe, 201-217, New York, Palgrave Macmillan.

Kucharczyk, J. - Mesežnikov, G. (2015a): The Visegrad countries have a stake in the success of a pro-European Ukraine, in Kucharczyk, J. - Mesežnikov, G., eds., Diverging Voices, Converging Policies: The Visegrad States' Reactions to the Russia-Ukraine Conflict, 9-12,Warsaw, Heinrich Böll Stiftung.

Kucharczyk, J. - Mesežnikov, G. (2015b): Diverging voices, converging policies, in: Kucharczyk, J. - Mesežnikov, G., eds., Diverging Voices, Converging Policies: The Visegrad States' Reactions to the Russia-Ukraine Conflict, 195-205, Warsaw, Heinrich Böll Stiftung. 
Kużelewska, E. - Bartnicki, A.R. - Skarzyński, R. (2015): Origins of and perspectives for the future for the Visegrad Group, in Piekutowska, A. - Wrońska, I., eds., Ten years of Visegrad Group Member States in the European Union, 145-158, Warsaw, Oficyna Wydawnicza ASPRA.

Luif, P. (2012): Austria and Central Europe, in Drulák, P. - Šabič, Z., eds., Regional and International Relations of Central Europe, 83-103, New York, Palgrave Macmillan.

Pehe, J. (2017): Střední Evropa je mizející sen, Lidové noviny (27 September): available at https:// www.novinky.cz/kultura/salon/450108-jiri-pehe-stredni-evropa-je-mizejici-sen.html (26 October 2017).

Romancov, M. (2002): Přežití střední Evropy optikou politické geografie, in Cabada, L. et al., eds., 69-83, Perspektivy regionu střední Evropy, Pilsen, University of West Bohemia.

Slovensko je európsky ostrov, hovorí Fico po vol'bách v Česku a spojil sa s Kiskom a Dankom (2017), Denník (23 October 2017): available at https://dennikn.sk/919225/slovensko-je-proeuropsky-ostrov-hovori-fico-po-volbach-v-cesku-a-spojil-sa-s-kiskom-a-dankom/ (26 October 2017).

Waisová, Š. (2002): Regionální integrace ve střední Evropě, in Cabada, L. et al., eds., Perspektivy regionu střední Evropy, 49-68, Pilsen, University of West Bohemia.

Walsch, C. (2015): Aufbruch nach Europa, Sieben Beiträge zur europäischen Integration Ungarns seit 1990. Herne: Gabrielle Schäfer Verlag.

Wandycz, P. S. (1998): Střední Evropa v dějinách od středověku do současnosti. Cena svobody. Prague: Academia.

Wientzek, O. (2017): Visegrad Cooperation: an Engine or Break for the European Integration Project. In Tungul, L., ed., The Czech Centre-Right Solutions to the Political Challenges of 2018, Prague, Wilfried Mertens Centre for European Studies, Konrad-Adenauer-Stiftung a TOPAZ: 45-50.

Wiśniewski, P. (2017): The Three Seas Initiative after the Wawsaw Summit: What Next? The Polish Quarterly of International Affairs 26(2): 55-64.

Ladislav Cabada studied Political Science at the Charles University in Prague/ Czech Republic; during his doctoral studies he spent one academic year at the University of Ljubljana/Slovenia. He works as Associate Professor and guarantee of study programmes Political science (M.A. and PhD. level) at the Department of Political Science and Humanities, Metropolitan University Prague/Czech Republic; he is also permament Visiting Scholar at the National University of Public Service in Budapest/Hungary. In his research he specializes on comparative politics of East-Central Europe, above all the party systems and political actors, and the analysis of selected East-Central European countries policies, and regional studies of Central and South-Eastern Europe. He is author or co-author of more than one hunderd scholar publications. Among the most recent we can mention books Od dunajské federace k Visegrádu... a zpět? Staré a novéformáty středoevropské spolupráce [From the Danubian Federation towards the Visegrad... and back? Old and new formats of Central European cooperation] (with Christopher Walsch, 2017), Balkánské komunismy [Balkan Communisms] (with Markéta Kolarčíková, 2016), Zahraniční poli- 
tika Slovinska [Slovenian Foregin Policy] (with Hana Hlaváčková, 2016), Současná komparativní politologie: Klíčové koncepty [Contemporary comparative politics: key concepts] (with Jakub Charvát and Ondřej Stulík, 2015) or Political Parties in East Central Europe (with Vít Hloušek and Petr Jurek, 2014).

E-mail: ladislav.cabada@mup.cz 